\title{
PENYELESAIAN SENGKETA KEPULAUAN SENKAKU ANTARA CHINA DAN JEPANG DALAM PERSPEKTIF HUKUM INTERNASIONAL
}

\author{
Kadek Try Suka Adnyana, Dewa Gede Sudika Mangku, Ratna Artha Windari \\ Jurusan IImu Hukum \\ Univeritas Pendidikan Ganesha \\ Singaraja, Indonesia
}

e-mail: $\{\underline{\text { kadektrysuka@gmail.com }}$, dewamangku.undiksha@gmail.com, ratnawindari@undiksha.ac.id\}

\begin{abstract}
ABSTRAK
Penelitian ini bertujuan untuk mengetahi dan mengkaji 1) status Kepulauan Senkaku menurut Hukum Internasional, 2) Penyelesaian Sengketa Internasional Kepemilikan Kepulauan Senkaku antara China dan Jepang. Penelitian ini merupakan penelitian yang menggunakan metode penelitian hukum normatif dengan pendekatan perundang-undangan (statue approach), pendekatan sejarah (historical approach) dan pedekatan fakta (fact approach). Data yang diperoleh dan diolah adalah data sekunder, pengumpulan data dilakukan mengunakan metode studi kepustakaan dengan mengumpulkan bahan hukum dan informasi yang berupabahan hukum primer, sekunder, maupun tersier. Dalam rangka mendapatkan pemaparan yang jelas, data-data tersebut kemudian disusun secara sistemmatis dan dianalisis dengan menggunakan metode deskriptif. Hasil penelitian ini menunjukan bahwa 1) Kepulauan Senkaku, Kepulauan yang tidak ada penghuni dan Kepulauan yang dalam setatus Quo, terbukti kedua negara China dan Jepang saling meng klaim ketika mengetahi adanya sumberdaya alam yang melimpah di Kepulauan Senkaku. 2) Dari semua perjanjian yang pernah dilakukan China dan Jepang tidak juga menemukan titik temu, China dan Jepang dapat menempuh cara-cara penyelesaian sengketa internasional. Sesuai dengan Pasal 33 Piagam PBB yang menyatakan, para pihak dalam suatu persengketaan yang tampaknya sengketa tersebut akan membahayakan perdamaian dan keamanan internasional, harus pertama-tama mencarai penyelesaian dengan cara negosiasi, penyelidikan, mediasi, konsiliasi, abitrase, pengadilan, menyerahkannya kepada organisas-organisasi atau badan-badan regional, atau caracara penyelesaian damai laiannya yang mereka pilih. Maka penyelsesaian yang harus dilakukan China dan Jepang yaitu penyelesaian sengketa secara damai, seperti Negosiasi, pencarian fakta, jasa-jasa baik dan apabila tidak juga menemukan penyelesaian, dapat menempuh International Court Of Justice / Mahkamah Internasional.
\end{abstract}

Kata kunci : Status Kepemilikan Kepulauan senkaku dan Penyelesaian Sengketa Internasional Kepulauan Senkaku

\begin{abstract}
The research is aimed at identifying and reviewing 1) Senkaku Islands status according to International Law, 2) International Settlement of Senkaku Islands Ownership Rights between China and Japan. This research is a research using normative law research method with statue approach, historical approach and fact approach. The data obtained and processed is secondary data, data collection is done using literature study method by collecting legal material and information which have primary, secondary, and tertiary law. In order to obtain clear exposure, the data are then arranged systemmatically and analyzed by using descriptive method. The results of this study show that 1) Senkaku Islands, non-existent islands and islands within Quatus, proved both Chinese and Japanese states claimed each other when they were aware of the abundant natural resources of the Senkaku Islands. 2) Of all the agreements China and Japan have not even met, China and Japan can pursue ways of resolving international disputes. In accordance with Article 33 of the UN Charter stating, the parties to a dispute that appears to be at risk of international peace and security shall first seek settlement by way of negotiation, inquiry, mediation, conciliation, abitration, court, to the organizations or regional bodies, or their preferred means of peace settlement. Therefore, China and Japan must
\end{abstract}


settle the settlement of disputes peacefully, such as negotiation, fact finding, good services and if not found solutions, can take the International Court of Justice / International Court of Justice.

Keywords: Senkaku Islands Ownership Status and International Dispute Settlement Senkaku Islands.

\section{PENDAHULUAN}

Hukum internasional dapat didefinisikan sebagai keseluruhan hukum yang untuk sebagian besar terdiri dari prinsip-prinsip dan kaidah-kaidah prilaku yang terhadapnya negara-negara merasa dirinya terikat untuk menaati, dan karenanya, benar-benar ditaati secara umum dalam hubungan-hubungan mereka satu sama lain (Djajaatmadja, 2004: 3).

Pada akhir tahun 1982 masyarakat internasional telah berhasil dalam menyusun suatu perangkat hukum hukum yang baru, yang disebut Konvensi Hukum Laut 1982 (United Convention on The Law of The Sea of 1982/ UNCLOS III) yang disahkan di Teluk Montego pada tanggal 10 Desember 1982 berisi ketentuanketentuan yang mengatur pembagian zona maritim dengan status hukum yang berbeda-berbeda. Secara garis besar, Konvensi membagi laut ke dalam dua bagian zona maritim yaitu zona-zona yang berada di bawah dan di luar yurisdiksi nasional (Sodik, 2014 : 19).

Terkait hubungan-hubungan internasional yang diadakan antarnegara, negara dengan individu, atau negara dengan organisasi internasional tidak selamanya terjalin dengan baik. Acap kali hubungan itu menimbulkan sengketa di antara mereka. Sengketa dapat bermula dari berbagai sumber potensi sengketa. Sumber potensi sengketa antarnegara dapat berupa perbatasan, sumber daya alam, kepulauan, perdagangan dan lainlain. Dalam studi hukum internasional publik, dikenal dua macam sengketa internasional, yaitu sengketa hukum (legal or judicial disputes) dan sengketa politik (political or nonjusticiable diputes). Sebetulnya tidak ada kriteria yang jelas dan diterima secara umum mengenai pengertian kedua istilah tersebut. Yang kerapkali dipakai menjadi ukuran suatu sengketa di pandang menjadi sengketa hukum yaitu mana kala sengketa tersebut bisa atau dapat diserahkan dan diselesaikan oleh pengadilan internasional (Adolf, $2004: 3$ ).

Namun pandangan demikian sulit diterima. Sengketa-sengketa Internasional, secara teoretis pada pokoknya selalu dapat diselesaikan oleh pengadilan internasional. Sesulit apa pun suatu sengketa, sekalipun tidak ada pengaturannya, suatu pengadilan internasional tampaknya bisa memutuskannya bergantung dengan prinsip kepatutan dan kelayakan (ex aequa et bono) (Adolf, $2004: 3$ ).

Pada pokoknya, ada banyak sengketa yang bisa diserahkan dan kemungkinan besar bisa diselesaikan oleh pengadilan internasional. Tetapi karena salah satu atau kedua negara enggan menyerahkan kepada pengadilan, pengadilan tidak menjadi berwenang mengadilinya. Dalam hal ini, yang menjadi dasar hukum bagi pengadilan untuk melaksanakan yuridiksinya adalah kesepakatan para pihak yang bersengketa.

Hubungan bilateral yang kurang baik antara China dan Jepang bukan hanya dipengaruhi oleh faktor sejarah saja, tetapi masalah perebutan Kepulauan Senkaku menjadi konflik yang masih berlangsung. China dan Jepang saling mengklaim bahwa Kepulauan Senkaku miliknya. Kepulauan Senkaku yang diperebutkan China dan Jepang adalah kepulauan seluas $7 \mathrm{~km}$ yang terletak pada $175 \mathrm{~km}$ dari utara Pulau Ishigaki (bagian wilayah Okinawa), $190 \mathrm{~km}$ timur laut Taiwan dan $420 \mathrm{~km}$ dari timur daratan China (Furqan,2013:1).

Kepulauan Senkaku hanyalah pulau kecil tanpa berpenghuni manusia, tetapi Kepulauan Senkaku memiliki 85\% sumber daya alam minyak bumi dan gas alam. Hal tersebut yang menyebabkan kedua negara Jepang dan China sama-sama bersikeras untuk mempertahankannya. Pemerintah Jepang menganggap pulau 
tersebut sebagai bagian dari Prefektur Okinawa. Pandangan China, Jepang menyerah tanpa syarat kepada Sekutu sehingga lahir Perjanjian Postdam di tanggal 26 Juli 1945 yang salah satu isinya kekuasaan Jepang hanya dibatasi pada Kepulauan Honshu, Hokkaido, Kyushu, Shikoku, sedangkan pulau-pulau kecil lainnya ditentukan oleh negaranegara sekutu (Furqan,2013:1).

Adanya perbedaan paham garis perbatasan laut di Laut China Timur (The East China) antara China dan Jepang hingga kini belum dicapai kesepakatan bersama. Walau kedua negara samasama meratifikasi Konvensi PBB tentang Hukum Laut (UNCLOS) 1982, tetapi mereka membangun pemahaman sendiri yang belum tutas dibicarakan, diantaranya, Jepang mengusulkan pembagian wilayah berdasar garis tengah di zona ekonomi eksklusifnya berjarak 200 mil dari garis dasar/baseline. Mengenai paham garis ala Jepang memang tidak sesuai dengan isi Konvensi. Menurut pakar hukum laut dari China menegaskan bahwa pengambilan garis tengah untuk mengukuran ZEE dan landasan kontinental seharusnya didasarkan pada sebuah perjanjian antarkedua pihak agar agar tercapai solusi yang adil (Roza, 2012 :6).

China mengacu pada kelanjutan alamiah dari landas kontinenya berjarak di luar 200 mil. Yang mana dalam Hukum Laut Internasional Ladas kontinen meliputi dasar laut dan tanah dibawahnya dari area di bawah permukaan laut yang terletak di luar laut teritorial, sepanjang kelanjutan alamiah wilayah daratan hinnga pinggiran laut tepi kontinen, atau hingga suatu jarak 200 mil laut dari garis pangkal dari mana lebar laut teritorial diukur, dalam hal pinggiran luar tepi kontinen tidak mencapi jarak tersebut, hingga paling jauh 350 mil laut sampai dengan jarak 100 mil laut dari garis kedalaman 2.500 meter (Roza, $2012: 6$ ).

Adapun faktor pemicu ketegangan antar China dan Jepang iyalah perbedaan paham garis perbatasan laut di Laut China Timur antara Jepang dan China hingga kini belum dicapai kesepakatan bersama.
Walau keduanya sama-sama meratifikasi Konvensi PBB tentang Hukum Laut (UNCLOS) 1982, tetapi mereka membangun pemahaman sendiri yang belum tuntas dibicarakan.

Jepang mengusulkan pembagian wilayah berdasar garis tengah di zona ekonomi eksklusifnya (berjarak 200 mil dari garis dasar/baseline) sedangkan China mengacu pada kelanjutan alamiah dari landas kontinennya (berjarak di luar 200 mil) (Kusumah, 2014: 1)

Terkait dengan sengketa China dan Jepang dalam memperebutkan Kepulauan Senkaku tersebut penulis tertarik untuk membuat sebuah tulisan hukum dengan judul Penyelesaian Sengketa Kepulauan Senkaku Antara China dan Jepang Dalam Perspektif Hukum Internasional.

Rumusan masalah dalam penelitian ini iyalah : 1) Bagaimana status kepemilikan Kepulauan Senkaku menurut Hukum Internasional. 2) Bagaimana Penyelesaian Sengketa Internasional kepemilikan Kepulauan Senkaku antara China dan Jepang.

Tujuan dari penelitian ini iyalah : 1) Untuk mengetahui status kepemilikan Kepulauan Senkaku menurut hukum internasional, 2) Untuk mengetahui penyelesaian sengketa internasional kepemilikan Kepulauan Senkaku antara China dan Jepang.

Manfaat yang diproleh dari penelitian ini iyalah : 1) Penelitian ini diharapkan dapat memberikan pemahaman mengenai Sengketa Kepulauan Senkaku antara China dan Jepang yang sejak lama di perebutkan, selain itu juga diharapkan dapat menjadi refrensi tambahan guna untuk pengembangan ilmu hukum kususnya di bidang hukum internasional mengenai analisis yuridis terhadap Sengketa internasional kepulauan Senkaku antara China dan Jepang, 2) Penelitian ini diharapkan dapat bermanfaat bagi masyarakat Internasional sebagai sarana pengembangan pemikiran tentang penyelesaia sengketa internasional Kepulauan senkaku antara China dan Jepang, ditinjau dari hukum internasional. Selain itu diharapkan masyarakat internasional dapat 
mengetahui mengenai pentingnya upaya menyelesaikan sengketa Internasional terkait dengan kasus sengketa internasional Kepulauan senkaku antara China dan Jepang.

\section{METODE PENELITIAN}

Jenis penelitian yang digunakan penulis dalam penelitian ini merupakan jenis penelitian hukum normatif, penelitian hukum normatif yaitu penelitian yang dilakukan dengan cara mengkaji konvensikonvensi yang berlaku atau diterapkan terhadap suatu permasalahan internasional tertentu. Penelitian normatif seringkali disebut dengan penelitian doktrinal, yaitu penelitian yang objek kajiannya adalah konvensi-konvensi dan bahan pustaka (Soejono dan Abdurahman, 2003:56).

Penelitian ini, menggunakan jenis penelitian hukum normatis karena akan mengkaji UNCLOS dan Penyelesaian Sengketa Internasional terkait Penyelesaian sengketa kepulauan senkaku antara China dan Jepang.

Jenis pendekatan dalam penelitian ini adalah : 1) Pendekatan sejarah, 2) Pendekatan Perundang-undangan, 3) Pendekatan Fakta. Sumber bahan hukum yang diperoleh dan diolah dalam penelitian hukum normatif merupakan data sekunder yang diperoleh dari sumber kepustakaan yang terdiri dari : 1) Bahan hukum primer, 2) Bahan Hukum Sekunder, 3) Bahan hukum tersier.

Teknik pengumpulan bahan hukum yang dilakukan adalah dengan cara menggali kerangka normatif menggunakan bahan hukum yang membahas tentang teori-teori hukum, penyelesaian sengketa internasional pulau sengkaku antara China dan Jepan. Baik bahan hukum primer maupun bahan hukum sekunder dikumpulkan berdasarkan topik permasalahan yang telah dirumuskan berdasarkan diklasifikasi menurut sumber dan hierarkinya untuk dikaji secara kompeherensif.

\section{PEMBAHASAN \\ Status Kepemilikan Kepulauan Senkaku menurut Hukum Internasional}

Kepulauan Senkaku/Diaoyutai terdiri dari 5 pulau vulkanik kecil dan 3 batu karang, kedua duanya memiliki nama atau sebutan dari bahasa China dan Jepang, pulau-pulau serta batu karang tersebut berkumpul mengelilingi satu pulau yang terbesar yang bernama pulau Uotsuri/Diaoyu, dan total luas pulau Uotsuri/Diaoyu sendiri adalah 8 hektar. Pulau-pulau kecil yang bernama Kobisho/ Huangwei $\mathrm{Yu}$ dan Akao-sho/Chiwei Yu berada pada $31 \mathrm{~km}$ dan $108 \mathrm{~km}$ dari pulau Uotsuri/Diaoyu, dan perlu diketahui bahwa tidak satupun dari pulau-pulau kecil tersebut berpenghuni. Dan total area daratan Kepulauan Senkaku/ adalah 7 km persegi (Tamisari, $2017:$ 1).

Sebuah Kepulauan yang di Jepang biasa dipanggil dengan Kepulauan Senkaku sedangkan di China, Kepulauan tersebut dikenal dengan nama Diaoyutai, sejak tahun 1970 sampai sekarang masih menjadi sebuah wilayah yang disengketakan oleh China dan Jepang (Tamisari, $2017:$ 2).

Sejarah awal Kepulauan Senkaku, dimulai dari zaman Dinasti Ming sampai terjadinya sengketa terhadap Kepulauan Senkaku. Dapat diketahui bahwa pada abad 15, Kepulauan Senkaku merupakan bagian dari wilayah China dan hal tersebut dapat dibuktikan dari sebuah dokumen yang dibuat oleh Chen Kan tentang perjalanannya menuju kerajaan Ryukyu, yang merupakan sebuah keajaan yang statusnya berada dibawah kekuasaan Dinasti Miing. (Millati, 2009 : 47).

Di satu sisi, penguasa Jepang pada waktu yang bernama Shimazu,telah berhasil menaklukkan Kerajaan Ryukyu pada tahun 1609, dan mengakibatkan kerajaan Ryukyu masuk kedalam salah satu daerah jajahan Jepang pada waktu itu. Dari keterangan diatas, dapat dikatakan bahwa Kepulauan Senkaku pada abad ke 15 sampai ke 16 masih menjadi bagian dari wilayah China. Namun, apa mau dikata, Kepulauan Senkaku itu hanyalah kepulauan kecil yang tidak berpenghuni dan sampai akhir abad ke 16-pun Kepulauan Senkaku hanya dipakai sebagai alat petunjuk yang dapat mengarahkan para pelayar dari 
China yang ingin menuju ke Ryukyu. dan sejak penaklukkan Shimazu atas Ryukyu Kepulauan Senkaku menjadi sebuah kepulauan yang terabaikan (Furquan, $2013: 2)$.

Hingga abad 17 dan 18, Kepulauan Senkaku tetap tidak menjadi kepulauan yang mempunyai arti penting bagi China dan Jepang, walaupun telah banyak peristiwa dan perubahan yang terjadi pada China dan Jepang, keadaan Kepulauan Senkaku masih tetap seperti masa-masa sebelumnya yaitu sebuah Kepulauan kosong yang tidak berpenghuni (Tamisari, $2017: 3)$.

Dan tahun ketika Ryukyu telah masuk kedalam bagian dari Perfektur Okinawa, itu juga merupakan tahun dimana konflik telah terjadi diantara pemerintah Dinasti Qing (China) dengan Pemerintah Jepang, mengenai pemberian sebutan terhadap daerah teritorial ini (daerah teritorial kerajaan Ryukyu) (Tamisari, $2017: 3$ ).

Pada tahun 1879, akhirnya Kepulauan Ryukyu telah resmi menjadi salah satu bagian dari Perfektur Okinawa. Dan diwaktu yang sama, Jepang juga telah menunjukkan minatnya pada Kepulauan Diaoyutai, yang letaknya berdekatan dengan Kepulauan Ryukyu (Tamisari, $2017: 4$ ).

Di dalam Peta territorial, Jepang membuat pembagian daerah perfektur, yang telah dipersiapkan dan dibentuk oleh Menteri Dalam Negeri. Pada tahun 1877 menteri dalam negeri memasukkan Kepulauan Diaoyutai kedalam bagian daerah perfektur Okinawa. Namun pada saat itu Kepulauan Diaoyutai atau Senkaku merupakan sebuah Kepulauan yang tidak dikenal (Millati, 2009 : 54).

Belum ada kejelasan tentang status Kepulauan Diaoyutai, dan dengan situasi yang ada, akhirnya seorang Gubernur Okinawa terpaksa mengambil sebuah tindakan, untuk mengesahkan dan memperjelas status Kepulauan Diaoyutai sebagai daerah wilayah kekuasaan Jepang (Roza, 2012 : 2).

Pada 13 januari 1890, Gubernur Okinawa mengirimkan sebuah surat kepada menteri dalam negeri Jepang.
Surat itu berisi permintaan Gubernur Okinawa kepada menteri dalam negeri Jepang untuk memberikan otoritas kepada Gubernur Okinawa dalam pengadaan sebuah tower ataupun mercusuar sebagai suatu bentuk penanda daerah kekuasaan Jepang. Namun apa mau dikata, pemerintah memang sudah tidak mempunyai kepedulian, karena sekali lagi pemerintah telah memberikan penolakannya disebabkan oleh ketegangan hubungan yang terjadi dengan China. Walaupun hal tersebut terjadi, pemerintah Jepang dan Pemerintah China khususnya tidak memberikan larangan kepada nelayan Jepang yang memancing disekitar wilayah Kepulauan Diaoyutai, karena Jepang dan China telah meyakini bahwa Kepulauan Diaoyutai merupakan sebuah Kepulauan yang tidak berpenghuni (Roza, $2012: 3$ ).

Situasi yang tenang dan damai antara kedua negara terhadap kepemilikan Kepulauan Senkaku tidak berlangsung lama. Karena pada tahun 1968, ada beberapa penelitian yang dilakukan oleh UNCAFE (UN Economic Commission for Asia and the Far East) yang menyatakan bahwa di Laut China Timur, tepatnya di sebuah landas continental dekat Kepulauan Senkaku, terdapat kandungan minyak dan gas alam yang besar, dan kandungan minyak serta gas alam tersebut itu akan menjadi salah satu kandungan minyak terbesar di dunia. Oleh sebab itu, maka hal yang besar akhirnya terjadi pada Kepulauan Senkaku, dimana Kepulauan Senkaku yang dahulunya adalah sebuah Kepulauan yang tidak memiliki arti yang penting, baik bagi Jepang maupun bagi China.

Setelah para peneliti itu mengeluarkan pernyataan tersebut, status kepemilikan kepulauan Senkaku akhirnya menjadi penting dan diperebutkan oleh kedua negara yaitu China dan Jepang ((Furquan, 2013: 5).

Berdasarkan penjelasan tentang awal mula sengketa, dapat disimpulkan bahwa Kepulauan Senkaku, kepulauan yang tidak ada yang memiliki, baik China maupun Jepang, hanya saja kedua negara memiliki kepentingan nasional 
terhadap Kepulauan Senkaku seperti Jepang yang ingin memperluas daerah terirorialnya ketika pada tanggal 13 Januari 1890 Gubernur Okinawa mengirimkan sebuah surat kepada Menteri dalam negri Jepang. Surat yang berisi permintan, permohonan Gubernur Okinawa kepada Menteri dalam Negeri Jepang untuk memberikan otoritas kepada Gubernur Okinawa dalam pengadaan sebuah tower atau mercusuar sebagai bentuk penanda daerah kekuasaan Jepang, dan Jepang menolak permintaan Gubernur Okinawa, yang disebabkan oleh ketegangan hubungan yang terjadi dengan China.

Akhirnya Pada 14 Januari 1895, Pemerintah menyetujui permintaan Gubernur Okinawa, ditambah lagi dengan adanya hasil penelitian yang dilakukan oleh UNCAFE (UN Economic Commission for Asia and the Far East) yang menyatakan bahwa di Laut China Timur, tepatnya di sebuah landas continental dekat Kepulauan Senkaku, terdapat kandungan minyak dan gas alam yang besar, hal ini lah yang menyebabkan Jepang tidak ingin melepaskan Kepulauan Senkaku dan memberikan klaim klaim terhadap kepulauan Senkaku.

Sedangkan China, China yang sebelumnya menelantarkan kepulauan senkaku serta menggantungkan status kepemilikan kepulauan senkaku yang pada akhirnya China mengetahui kekayaan alam yang dimiliki oleh Kepulauan Senkaku sehingga China membantah klaim Jepang atas kepulauan senkaku karena menurut China Kepulauan Senkaku termasuk dalam Tauwan. China juga mempertahankan Kepulauan Senkaku dengan cara sejarah kepulauan senkaku dan perjanjianperjanjian yang berkaitan dengan Kepulauan Senkaku, serta China melihat sejarah di masa lalu yang dulu dijajah oleh Jepang kini China tidak ingin mengalah kepada Jepang. Inilah yang membuat China mempertahankan Kepulauan Senkaku.

Ada beberapa hal yang mendukung Kepulauan Senkaku tidak ada yang memiliki yaitu perbedaan paham garis perbatasan laut di Laut China Timur (The East China) antara China dan Jepang hingga kini belum dicapai kesepakatan bersama. Walau kedua negara samasama meratifikasi Konvensi PBB tentang Hukum Laut (UNCLOS) 1982, tetapi mereka membangun pemahaman sendiri yang belum tutas dibicarakan, diantaranya

\section{a. Jepang}

Jepang mengusulkan pembagian wilayah berdasar garis tengah di zona ekonomi eksklusifnya berjarak 200 mil dari garis dasar/baseline. Mengenai paham garis ala Jepang memang tidak sesuai dengan isi Konvensi. Menurut pakar hukum laut dari China menegaskan bahwa pengambilan garis tengah untuk mengukuran ZEE dan landasan kontinental seharusnya didasarkan pada sebuah perjanjian antarkedua pihak agar agar tercapai solusi yang adil (Roza, 2012 : 6).

b. China

China mengacu pada kelanjutan alamiah dari landas kontinenya berjarak di luar 200 mil. Yang mana dalam Hukum Laut Internasional Ladas kontinen meliputi dasar laut dan tanah dibawahnya dari area di bawah permukaan laut yang terletak di luar laut teritorial, sepanjang kelanjutan alamiah wilayah daratan hinnga pinggiran laut tepi kontinen, atau hingga suatu jarak 200 mil laut dari garis pangkal dari mana lebar laut teritorial diukur, dalam hal pinggiran luar tepi kontinen tidak mencapi jarak tersebut, hingga paling jauh 350 mil laut sampai dengan jarak 100 mil laut dari garis kedalaman 2.500 meter (Roza, 2012 :6).

\section{Upaya Penyelesaian Sengketa Internasional Kepemilikan Kepulauan Senkaku antara China dan Jepang}

Dalam sengketanya terhadap Kepulauan Senkaku, China dan Jepang memiliki klaim yang berbeda atas 
Kepulauan Senkaku, diantaranya (Tamisari, $2017: 15)$. :

Klaim China :

a. Cina menyebutkan bahwa di dalam dokumen sejarah jepang telah dijelaskan bahwa Kepulauan Senkaku merupakan bagian dari wilayah kedaulatan China

b. Cina juga menyatakan bahawa Kepulauan Senkaku dan Taiwan itu merupakan sebuah satu kesatuan dimana keduanya diserahkan kepada Jepang melalui sebuah aturan yang terdapat didalam perjanjian Shimonoseki, dikarenakan kemenangan Jepang pada Perang China dan Jepang tahun 1895. Isi dari perjanjian Shimonoseki keharusan China menyerahkan sebagian wilayahnya ke Jepang.

c. China juga percaya jepang akan melepaskan kedaulatan pulaupulau itu dengan dua perjanjian yaitu perjanjian San Francisco tahun 1951 dan perjanjian China dan Jepang tahun 1952. Pada pasal 2 perjanjian San Francisco 1951 jepang wajib menyerahkan kembali Taiwan dan pulau-pulaua lainya ketangan China. Pada pasal 3 perjanjian San Francisco, AS berhak atas Perfektur Okinawa, dan AS akan mengembalikannya lagi ketangan Jepang pada tahun 1971. Dan disaat AS tidak melakukan perubahan pada setatus Kepulauan Senkaku, Jepang mendukung Kepulauan Senkaku untuk masuk kedalam bagian wilayah Perfektur Okinawa.

d. China juga menegaskan Proklamasi Postdam yang disepakati oleh sekutu juga memaksa Jepang untuk mengembalikan wilayah-wilayah yang dikuasai oleh Jepang, yang di dapatnya dari hasil kemenangan atas perang dengan China yang terjadi ditahun 1894-1895.

e. China Menyatakan memiliki datadata yang berupa beberapa arsiparsip sejarahdi zaman kerajaan
China yang mana arsip-arsip tersebut menyatakan bahwa sejak tahun 1373 China telah menduduki dan juga menggunakan serta memmanfaatkan kepulauan senkaku.

f. China menyatakan bahwa di abat ke enam belas di saat dinasti Ming menguasai daratan China, Kepulauan Senkaku telah dimasukan kedalam wilayah China sebagai salah satu daerah pertahanan pantai China. Berkaitan dengan masuknya Pulau Taiwan kedalam China dimasa dinasti Qing, dan banyaknya nelayan Taiwan yang memanfaatkan Kepulauan Senkaku, maka China menganggap bahwa dia telah memanfaatkan Kepulauan Senkaku dengan semaksimal mungkin. Sebab Taiwan merupakan bagian dari wilayah China.

Klaim Jepang :

Klaim Jepang atas Kepulauan Senkaku itu berdasarkan atas emapat hal, yang antara lain adalah:

a. Menurut Jepang, secara hukum Jepang memiliki hak untuk menganggap dan menyatakan Kepulauan Senkaku sebagai bagian dari wilayahnya, karena Kepulauan Senkaku merupakan Kepulauan yang tidak bertuan.

b. Karena Jepang telah meyakini bahwa secara hukum dia memiliki hak atas Kepulauan Senkaku, sehingga, bagi Jepang Kepulauan Senkaku telah menjadi bagian dari wilayah Jepang dan bukan bagian dari wilayah Taiwan seperti yang dikatakan oleh China. Maka, Jepang akhirnya menganggap bahwa Kepulauan Senkaku tidak pernah menjadi bagian dari perjanjian Shimonoseki maupun perjanjian San Francisco.

c. Jepang juga meyakini bahwa dia telah menduduki dan mempunyai kedaulatan atas Kepulauan Senkaku dalam waktu yang lama, 
dan hal tersebut bagi Jepang merupakan suatu alasan yang kuat untuk menyatakan bahwa Jepang telah memiliki kekuasaan dan kedaulatan yang sah terhadap Kepulauan Senkaku.

d. Bagi Jepang, perjanjian San Francisco tidak secara spesifik menerangkan tentang keterlibatan Kepulauan Senkaku sebagai salah satu bagian dari beberapa wilayah Jepang yang akan diserahkan kepada China.

Sengketa Cina dan Jepang, sebelumnya terdapat perjanjian perjanjian yang dianggap berhubungan dengan Kepulauan Senkaku, diantaraya (Rahmanto, 2014 : 70). :

a. Perjanjian Shimonoseki 1895.

Dalam hal ini dapat diketahui bahwa perjanjian Shimonoseki bukan hanya sekedar perjanjian perdamaian, tetapi juga sebuah perjanjian yang ditawarkan dan telah disetujui oleh kedua belah pihak untuk mengakhiri perang yang terjadi diantara keduanya, yaitu China dan Jepang (Rahmanto, 2014 : 72).

b. War Time Declaration (Deklarasi Kairo).

Deklarasi Kairo juga berisi tentang pengembalian seluruh wilayah Jepang seperti Manchuria, Formosa dan Pescadores, ke China, yang mana wilayah-wilayah tersebut didapat Jepang atas kemenanganya pada saat perang dengan China. Jepang juga dikeluarkan dari seluruh daerah yang didapat dan dikuasainya melalui kekerasan, pemaksaan dan juga ketamakannya. Pada 2 Agustus 1945, Perdana Menteri Inggris Winston Churchill, Presiden AS Harry Truman, dan Perdana Menteri Rusia Joseph Stalin, menandatangani Proklamasi Postdam. Proklamasi Postdam ini dilaksanakan pada 26 Juli 1945, dibawah judul "Proclamation Defining Terms for Japanese Surrender" (Rahmanto, 2014 : 73).

Perlu diketahui juga bahwa Kepulauan Senkaku sebenarnya tidak termasuk kedalam Deklarasi Kairo, namun, China percaya bahwa Kepulauan Senkaku termasuk dalam wilayah Formosa (Taiwan). Pernyataan lebih lanjut akhirnya ditegaskan bahwa Kepulauan Senkaku masuk kedalam bagian dari pulau-pulau yang didapat Jepang sebagai hasil dari kemenangan Jepang atas China pada perang China-Jepang yang pertama (Rahmanto, 2014 : 73).

c. San Francisco Peace Treaty 1951

Pada San Francisco Peace Treaty pasal 2, 8 September 1951, disebutkan bahwa Jepang harus melepaskan semua haknya terhadap Formosa (Taiwan) dan juga Pulau Pescadores.62 Dan didalam pasal 3, disebutkan bahwa Jepang harus mematuhi dan menyetujui semua permintaan Amerika Serikat, karena Jepang adalah Negara perwalian AS

Disamping fakta yang
menyebutkan bahwa Kepulauan
Senkaku tidak disebut secara
spesifik didalam perjanjian San
Francisco, ternyata perjanjian San
Francisco didalam salah satu draft
perjanjiannya, 19 Maret 1947 ,
menjelaskan tentang batas-batas
wilayah Jepang setelah Perang
Dunia ke II.

d. Perjanjian Damai antara China dan Jepang tahun 1952

Pada pasal 4, perjanjian perdamaian antara China dan Jepang tahun 1952 disebutkan bahwa, " semua perjanjian, konvensi, dan persetujuan yang ditandatangani dan disetujui oleh China dan Jepang sebelum tanggal 9 Desember 1941, yang 
telah dilakukan sebagai suatu konsekwensi dari perang, itu menjadi batal dan tidak berlaku". Menurut pandangan dan pemikiran Negara China, tujuan dari perjanjian damai ini secara tidak langsung adalah sebagai alat untuk membatalkan serta tidak memberlakukan perjanjian Shimonoseki, dan oleh karena itu, penyerahan Kepulauan Senkaku itu dibatalkan dan dikembalikan bersama dengan Pulau Formosa.

Dari perjanjian - perjanjian yang pernah dilakukan China dan Jepang tidak juga mendapat titik terang penyelesaian sengketa Kepulauan Senkaku, karena kedua negara China dan Jepang saling mengakui Kepulauan Senkaku, terbukti dengan adanya klaimklaim dari China dan Jepang.

Sebelumnya pada tahun 2006 tepatnya pada 9 januari 2006 China dan Jepang pernah melakukan perundingan tentang Kepulauan Senkaku. Pada perundingan ini telah terjadi kesepakatan antara kedua belah pihak untuk bersamasama mengelola Kepulauan Senkaku, selaian untuk meningkatkan hubungan yang selama ini tidak terjalin baik, China dan Jepang bermaksud untuk memperoleh keuntungan bersama. Tetapi dalam kesepakatan itu belum ada sepakat mengenai berapa investasi dari kedua belah pihak dan bagaimana membagi hasil keuntungan. Namun kesepakatan itu tak berjalan setelah ada protes dari masing masing negara, sengingga kesepakatan China dan Jepang tak berjalan.

Sesuai dengan Pasal 33 Piagam PBB yang menyatakan, para pihak dalam suatu persengketaan yang tampaknya sengketa tersebut akan membahayakan perdamaian dan keamanan internasional, harus pertama-tama mencarai penyelesaian dengan cara negosiasi, penyelidikan, mediasi, konsiliasi, abitrase, pengadilan, menyerahkannya kepada organisas-organisasi atau badan-badan regional, atau cara-cara penyelesaian damai laiannya yang mereka pilih.
Maka dalam penyelesaian sengketa Kepulauan Senkaku antara China dan Jepang, jika kedua negara ingin menyelesaikan sengketa secara damai maka hal pertama yang dapat di tempuh China dan Jepang adalah Negosiasi. Di karnakan sebelumnya China dan jepang pernah melakukan negosiasi pengelolaan bersama Kepulauan Senkaku, maka yang dapat dilakukan China dan Jepang ialah melanjutkan kesepakatan Pengelolaan bersama Kepulauan Senkaku.

Kerangka dasar tersebut menjadi dasar upaya kedua negara untuk mengadakan perjanjian pengelolan bersama (Joint Development), sampai kedua negara dapat menetapkan kesepakatan delimitasi akhir berdasarkan pada prinsip-prinsip saling menguntungkan atau mutual benefit principles. Proses awal negosiasi dalam Joint Development Jepang dan China, ialah dengan membentuk dan mengadakan penelitian letak stategis titiktitik pengelolaan bersama yang dapat di capai oleh kedua belah pihak. Selain itu, kedua negara juga mempercepat proses konsultasi dan data yang konkrit nantinya akan menjadi asas atau prinsip dalam kerjasama pengelolaan bersama Joint Development.

Apa bila Negosiasi yang dilakukan
China dan Jepang tidak terjalin
Kesepakatan, China dan Jepang dapat
memilih alternatif Penyelesaian laiannya
seperti :

\section{a. Pencarian Fakta}

Selanjutnya hal yang dapat di tempuh China dan Jepang iyalah Pencarian Fakta. Salah satu penyebab munculnya sengketa antar negara adalah karena adanya ketidaksepakatan para pihak mengenai fakta. Untuk menyelesaikan sengketa ini, akan bergantung pada penguraian fakta-fakta para pihak yang tidak disepakati. Untuk menyelesaikan sengketa ini, para pihak China dan Jepang harus membentuk sebuah badan yang bertugas 
untuk menyelidiki fakta-fakta yang terjadi di lapangan. Faktafakta yang ditemukan ini kemudian dilaporakan kepada para pihak China dan Jepang sehingga para pihak dapat menyelesaikan sengketanya.

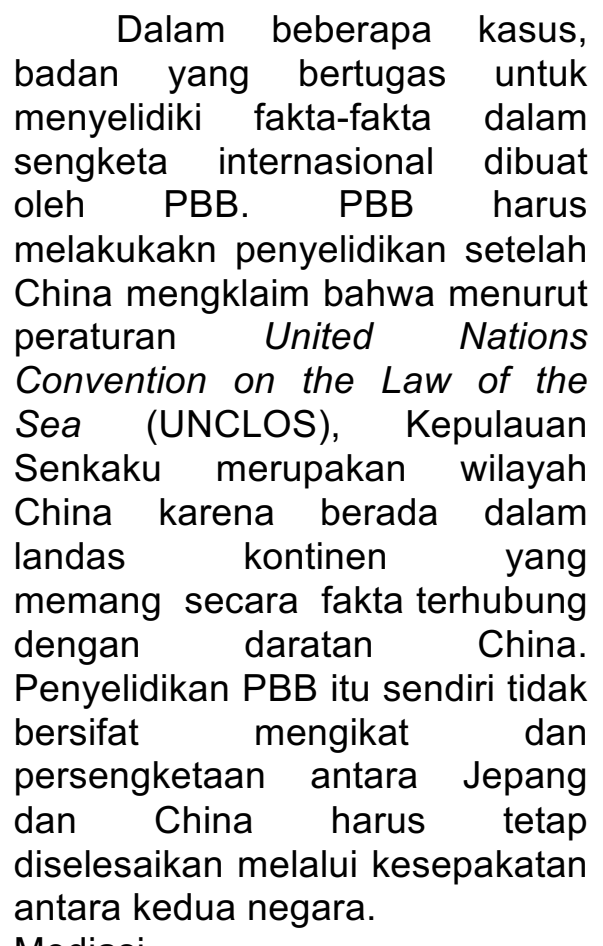

b. Mediasi

Berikutnya nediasi.
Ketika negara-negara yang
menjadi para pihak dalam suatu
sengketa internasional tidak
dapat menemukan pemecahan
masalahnya melalui negosiasi,
intervensi yang dilakukan oleh
pihak ketiga adalah sebuah cara
yang mungkin untuk keluar dari
jalan buntu perundingan yang
telah terjadi dan memberikan
solusi yang dapat diterima oleh
kedua belah pihak. Pihak ketiga
yang melaksanakan mediasi ini
tentu saja harus bersifat netral
dan independen. Sehingga dapat
memberikan saran yang tidak
memihak salah satu negara pihak
sengketa. Intervensi yang
dilakukan oleh pihak ketiga ini
dapat dilakukan dalam beberapa
bentuk. Misalnya, pihak ketiga
memberikan saran kepada kedua

belah pihak China dan Jepang untuk melakukan negosiasi ulang, atau bisa saja pihak ketiga hanya menyediakan jalur komunikasi tambahan. Dalam menjalankan tugasnya, mediator tidak terikat pada suatu hukum acara tertentu dan tidak dibatasi pada hukum yang ada.

Apa bila dalam penyelesaian di atas tidak mendapatkan jalan keluar, cara terahir dalam penyelesaian sengketa Kepulauan Senkaku antara China dan Jepang, melalui International Court Of Justice / Mahkamah Internasional.

Didirikannya International Court Of Justice adalah untuk menyelesaikan kasus-kasus persengketaan dengan cara damai dan dilarang menggunakan cara kekerasan, sehingga Negara-negara yang sedang bersengketa tidak perlu menyelesaikan sengketa dengan cara kekerasan. Tugas utama dari International Court Of Justice adalah untuk menyelesaikan sengketa-sengketa internasional mencakup bukan saja sengketa-sengketa antar Negara saja, melainkan juga kasus-kasus lain yang berada dalam lingkup pengaturan internasional. Dalam menyelesaikan sengketa antar Negara, Internasional Court of Justice mempunyai kewenangan / yuridiksi yang meliputi kewenangan untuk memutuskan perkara-perkara para pihak yang bersengketa dan kewenangan untuk memberikan Opini-opini / Nasihat kepada Negara-negara yang meminta, selain itu International Court Of Justice juga dapat memberikan opini / nasihat yang diminta oleh Majelis Umum dan Dewan Keamanan PBB, serta badan-badan lain dari PBB selama diijinkan oleh Majelis Umum. Dan berkaitan dengan putusan dari International Court Of Justice, putusan hanya mempunyai kekuatan mengikat terhadap pihak-pihak dan hanya berhubungan dengan perkara khusus dari para pihak tersebut. Putusan International Court Of Justice wajib dilaksanakan oleh pihak-pihak yang bersengketa, jika ada negara tidak mematuhi keputusan, maka ada beberapa sanksi yang diterapkan 
untuk memaksa negara tersebut mematuhinya.

\section{PENUTUP}

Adapun kesimpulan dari penelitian ini adalah : 1) Kepulauan senkaku kepulauan yang dalam status Quo serta Kepulauan yang tanpa penghuni, dilihat sebelum adanya penelitian dari UNCAFE (UN Economic Commission for Asia and the Far East) yang menyatakan bahwa di Laut China Timur, tepatnya di sebuah landas continental dekat Kepulauan Senkaku, terdapat kandungan minyak dan gas alam yang besar, kedua negara China dan Jepang tidak pemperdulihkan Kepulauan Senkaku dari setelah perang dunina II, setelah adanya informasi bahwa di dekat Kepulan Senkaku terdapat Sumberdaya alam yang melimpah, kedua negara China dan Jepang mengeluarkan klaim - klaim mereka untuk menguasai Kepulauan Senkaku. 2) Demi menghindari terjadinya penyelesaian sengketa dengan kekerasan antara China dan Jepang, China dan Jepang kembali melakukan negosiasi tentang kesepakatan pengelolaan Kepulan Senkaku bersama atau joint development, mengingat dulu di tahun 2006 kesepakatan itu belum menemukan kesepakatan berapa dana investasi dari China maupun Jepang dan pembagian hasil dari kepulauan senkakau.

Dikarenakan kedua negara China dan Jepang sama-sama memiliki tujuan untuk kemakmuran negaranya. Apabila dalam negosiasi tersebut tidak mendapatkan kesepakatan, Cina dan Jepang dapat mengunakann cara cara penyelesaian lain seperti Pencarian Fakta, dan mediasi. Apabila tidak juga mendapatkan hasil, cara terahir dalam Penyelesaian Sengketa Kepulauan Senkaku antara China dan Jepang melalui International Court Of Justicel Makamah Internasional.

Adapun saran berdasarkan penelitian ini adalah sebagai berikut :

1) Kepulauan senkaku yang kaya akan Sumberdaya alammnya yang hingga kini di perebutkan oleh Cina dan Jepang seharusnya dikelola oleh kedua negara China dan Jepang. China dan Jepang seharusnya kembali merundingkan tentang pengelolaan bersama Kepulauan Senkaku, yang pernah dilakukan di tahun 2006, serta menyepakati titik-titik pengelolaan bersama Kepulauan Senkaku. Ini akan menghindari terjadinya peperangan diantara kedua negra, memngingat kedua negara memiliki permiliteran yang kuat di Asia, apalagi China dan Jepang sama-sama memiliki kepentingan nasional terhadap kepulauan sengkaku.

2) Jika pengelolaan bersama tidak mendapatkan kesepakatan maka jalan terahir yang harus dilakukan adalah Penyelesaian sengketa melalui International Court Of Justice/ Makamah Internasional. Jika China dan Jepang benar benar merasa Kepulauan Senkaku memang miliknya, seharusnya kedua negara tidak takut jika kasus sengketanya di selesaiakan di Makamah Internasional.

\section{DAFTAR PUSTAKA}

\section{Buku}

Adolf, Huala. 1996. Aspek-Aspek Negara Dalam Hukum Internasional. Jakarta: PT Grafindo Persada.

Adolf, Huala. 2014. Hukum Penyelesaian Sengketa Internasional. Jakarta: Sinar Grafika.

Dam, Syamsumar. 2010. Politik Kelautan. Jakarta: Bumi Aksara.

${ }^{1}$ Dikdik Mohamad Sodik, 2014 Hukum Laut Internasional dan Pengaturannya di Indonesia,

F. Sugeng Istanto. Penelitian Hukum. Yogyakarta CV Ganda.

Soejono dan H Abdurahman. 2003. Metode Penelitian Hukum. Jakarta: Rineke Cipta.

\section{Jurnal}

Anugrah Hendri Rahmanto, 2014. Sengketa Kepulauan Senkaku antara China dan Jepang Volume 9 
No. 1 Program Studi S1 Hubungan Internasional Universitas Airlangga.

Daniel Kusumah, 2014. Posisi Senkaku Menurut Hukum Internasional Volume 9. No.3 Jurnal Hukum Rechtldee. Fakultas Hukum Universitas Trunojoyo Madura.

Dewa Gede Sudika Mangku, Universitas Pendidikan Ganesha Singaraja. Volume XVII No. 3 Tahun 2012 Edisi September.

\section{Skripsi}

Aldo Rico Geraldi. 2013. Penyiksaan Falun Gong Oleh Pemerintah Republik Rakyat China Terkait Konvensi Anti Penyiksaan Tahun 1984. Skripsi. Jurusan IImu Hukum, Universitas Udayana.

Power Cina Pada Sikap Agresif Terhadap Jepang Pasca

si Jepang atas Senkaku/Diaoyu Tahun 2012 Skripsi Program studi S-1 IImu Hubungan Internasional, Universitas Airlangga Surabaya. 